\title{
Pengaruh Kecemasan Terhadap Minat Belajar Matematika Siswa
}

\author{
Eryanti Lisma ${ }^{1}$, Rahmadhani ${ }^{2}$, Machrani Adi Putri Siregar ${ }^{3}$ \\ ${ }^{1}$ Program Studi Bimbingan Konseling UMN Al-Washliyah, 2,3Program Studi Pendidikan Matematika UMN \\ Al-Washliyah \\ 1yantilisma3003@gmail.com, 2ramah.math@gmail.com, ㅉmachrani.adi.putri@gmail.com
}

\begin{tabular}{c|cc} 
First received: & Revised: & Final Accepted: \\
12 November 2019 & 07 December 2019 & 05 December 2019
\end{tabular}

\begin{abstract}
Anxiety is a condition that arises when there is a threat of helplessness, feelings of isolation. Anxiety is also a matter of excessive concern and internalized as well as a variety of summative symptoms that cause significant disturbances in social or work functions that cause a decrease in interest in learning mathematics in students. Interest has a very important role in the learning process because interest is one of the determining factors in the success or action of the instructor's objectives to be achieved. Students who are not interested in the subject matter will show less sympathetic, lazy and not passionate attitudes. The data collection method uses a questionnaire for learning interest variables. The purpose of this study was to determine the relationship of student anxiety to interest in learning mathematics. The research subjects were 30 students. Based on the results of the study, it was concluded that: (1) there was a relationship of students 'anxiety to the interest in learning mathematics, or in other words the interest in learning mathematics at all was related by students' anxiety in their interest in learning mathematics in the face of examinations, especially in mathematics; (2) there is no relationship of interest in learning mathematics, or in other words there is no relationship of interest in learning mathematics that students have in learning mathematics. The relationship of anxiety that occurs between mathematics learning interest and anxiety is negative 0,417 ; (3) as a stimulus, anxiety about learning interest has a proven influence on the relationship of students' anxiety to mathematics learning interest.
\end{abstract}

Keywords: Learning Anxiety, Student Anxiety, Mathematics Learning Interest.

\begin{abstract}
Abstrak
Kecemasan merupakan suatu kondisi yang muncul bila ada ancaman ketidakberdayaan, perasaan terisolasi. Kecemasan juga merupakan sesuatu kekhawatiran yang berlebihan dan dihayati serta berbagai gejala sumatif yang menyebabkan gangguan yang bermakna dalam fungsi sosial atau pekerjaan yang menimbulkan penurunan minat belajar matematika pada siswa. Minat memiliki peran yang sangat penting dalam proses belajar karena minat menjadi salah satu faktor penentuan dalam berhasil atau tindaknya tujuan pengajar yang akan dicapai. Siswa yang tidak berminat terhadap bahan pelajaran akan menunjukan sikap kurang simpatik, malas dan tidak bergairah. Metode pengumpulan data menggunakan kuesioner untuk variabel minat belajar. Tujuan penelitian ini adalah untuk mengetahui hubungan kecemasan siswa terhadap minat belajar matematika. Subjek penelitian berjumlah 30 orang siswa. Berdasarkan hasil penelitian, diperoleh kesimpulan bahwa: (1) terdapat adanya hubungan kecemasan siswa terhadap minat belajar matematika, atau dengan kata lain minat belajar matematika sama sekali ada hubungan oleh rasa cemas siswa dalam minat belajar matematika dalam menghadapi ujian khususnya dalam mata pelajaran matematika; (2) tidak terdapat hubungan minat belajar matematika, atau dengan kata lain minat belajar matematika tidak ada hubungan minat belajar matematika yang dimiliki siswa tersebut dalam pembelajaran matematika. Hubungan kecemasan yang terjadi antara minat belajar matematika terhadap kcemasannya negatif 0,417 ; (3) secara stimulus, rasa cemas terhadap minat belajar terbukti memiliki andil untuk mempengaruhi hubungan kecemasan siswa terhadap minat belajar matematika.
\end{abstract}

Kata Kunci: Kecemasan Belajar, Kecemasan Siswa, Minat Belajar Matematika. 


\section{PENDAHULUAN}

Rasa cemas, tegang dan takut menurut kebanyakan orang merupakan hal yang wajar dalam belajar, karena setiap orang merasakan hal-hal tersebut dalam belajar. Hubungan antara kecemasa terhadap minat belajar matematika Ashraft (2002) dapat dijelaskan dengan logika bahwa ketika seseorang memiliki kecemasan, maka memunculkan kecemasan dalam tes dan memberikan hasil yang tidak maksimal.

Hal ini sejalan dengan pendapat Siebar (dalam Sudrajat 2008) menyatakan bahwa kecemasan dianggap sebagai salah satu faktor penhambat dalam belajar yang dapat menganggu kinerja fungsi- fungsi kongnitif seseorang, seperti dalam berkonsentrasi mengingat, pembentukan konsep dan pemecahan masalah. Kecemasan yang sangat kuat perhatian hilang. Karena hilangan kontrol, maka tidak mampu melakukan apapun meskipun dengan perintah. Terjadi peningkatan aktifitas motorik, berkurangnya kemampuan berhubung dengan orang lain, penyimpangan persepsi persepsi dan hilanngnya pikiran rasional, tidak mampu berfungsi secara efektif. Biasanya disertai dengan disorganisasi kepribadian. Kecemasan yang terjadi ketika belajar matematika atau bisa disebut dengan (Mathematics Anxiety) tidak hanya dirasakan saat sekolah saja akan tetapi kecemasan yang akan terjadi ketikabelajar matematika juga di rasakan di perguruan tinggi. Menurut pembelajaran matematika merupakan salah satu bagian dari keseluruhan proses pendidikan disekolah. Jika dicermati secara teliti, sangat jelas bahwa pelajaran matematika dalam setiap kurikulum selalu diajarkan di setiap satuan pendidikan dan di setiap tingkatan kelas dengan porsi jam pelajaran jauh lebih banyak dari pada mata pelajaran lainnya.
Tingkat kecemasan menurut Peplau ada empat tingkat kecemasan yang alami olah individu yaitu: Pertama, kecmasan ringan yang dihubungkan dengan ketegangan yang dialami sehari-hari. Individu masih wspada serta lapang persepsinya meluas memajamkan mata. dapat memotivasi individu untuk belajar dan mampu memecahkan masalah secara efektif dan menghasilkan pertumbuhan dan kreatifitas. contohya: seseorang yang menghadapi ujuian akhir. Kedua, Kecemasan sedang yaitu individu terfokus hanya pada pikiran yang menjadi perhatiannya, terjadi penyempitan lapangan persepsi masih dapat melakukan sesuatu arahan orang lain, contohnya individu yang mengalami konflik dalam pekerjaan dan pelajaran. Ketiga, kecemasan berat yaitu lapangan persepsi individu sangat sempit. Pusat perhatiannya pada detail kecil (specifik) dan tidak dapat berfikir tentang hal-hal yang lain. seluruh perilaku dimaksudkan untuk mengurangi kecemasan dan perlu banyak perintah/ arahan untuk terfokus pada area lain. contoh, individu mengalami kehilangan harta benda becana alam dan penyanderaan. Keempat, Panik yaitu individu kehilangan kendali dri dan detail perhatian hilang. Karena hilang nya kontrol maka tidak mampu melakukan apapun meskipun dengan perintah. Terjadi peningkatan aktifitas motorik, berkurang nya kemampuan berhubungan dengan orang lain, penyimpangan pesepsi dan hilangnya pikiran rasional, tidak mampu berfungsi secara efektif. Contoh, individu dengan kepribadian pecah/ despersonalisasi (Suliswati, 2005:48).

Dalam proses pembelajaran mata pelajaran matematika, tedapat banyak faktor yang mempengaruhi prestasi belajar matematika siswa, salah satunya adalah rasa cemas pada minat belajar matematika. 
Salah satu bentuk perasaan seorang siswa ketika menghadapi ujiaan khusus ujian matematika adalah terjadinya perasaan tidak mengenakan atau merasa takut dan tenang. Beberapa siswa terkadang menyingkapi ujian sebagai sebuah permasalahan dalam hidupnya baik karena nantinya ia akan malu karena tidak mendapat nilai yang bagus atau karena merasa tidak percaya diri dengn persiapan yang dimilikinya.

Perasaan takut atau tegang dalam menghadapi suatu persoalan tersebut sering disebut kecemasan. Kecemasan ini biasanya disebabkan karena adanya beberapa siswa yang tidak dapat menyerap materi yang di pelajaran secara cepat atau bahkan sangat sulit untuk bersama dalam memahami materi yang dipelajari. Hal tersebut berdampak pada terjadinya kecemasan pada diri siswa yang cendrung berdampak negatif yang mana kecemasan yang dialami siswa akan semakin menanamkan keraguan pada diri siswa karena merasa tertinggal dan susah dalam memahami selanjutnya sehingga mempengaruhi prestasi belajar matematika. Selain merasa cemas dalam minat belajar matematika jyga merupakan salah satu faktor yang mempengaruhi prestasi belajar sangat dipengaruhi prestasi belajar matematika siswa. Minat belajar matematika adalah terkaitan dan apresis terhadap matematika, yaitu suatu kecendrungan untuk berfikir dan berindak dengan cara yang positif. Minat belajar siswa terhdap matematika terwujud melalui sikap dan tindakan dalam memilih pendekatan dalam menyelesaikan tugas.

Selain itu, siswa merasakan dirinya mengalami proses belajar saat menyelesaikan tantangan tesebut. Minat belajar matematika dipandang dalam menentukan keberhasilan belajar siswa. Siswa memerlukan minat belajar matematika yang akan menjadi mereka gigih menhadapi masalah yang lebih matang untuk bertanggung jawab terhadap belajar mereka sendiri dan untuk mengembangkan kebiasan baik dan cendrung mengurang beban belajar matematika dengan maksud untuk membantu siswa, padah itu merupakan sesuatu yang penting untuk siswa.

Tujuan penelitian ini adalah untuk mengetahui bukti adanya hubungan kecemasan dengan minat belajar. Selain itu juga peneliti ini juga diharapakn mampu memberikan informasi secara akademi kepada para tenaga pendidik dalam rangka meningkatkan prestasi belajar matematika siswa maupun kualitas pendidikan pada umumnya.

Tempat penelitian di SMP AsySyafi'iyah Internasional Medan, Jln. Karya Wisata No. 1 dimana kegiatan penelitian kegiatan di mulai bulan November 2018.

\section{METODE}

Metode penelitian ini adalah kuatitatif. Metode pengumpulan data menggunakan angket dalam mencari data minat belajar matematika (X) dan dokumentasi digunakan untuk memperoleh data minat belajar siswa (Y). Teknik analisis data menggunakan analisis regresi liner sederhana. Analisis ini untuk mengetahui arah hubungan antara variabel independent dengan variabel dependen. Apakah positif atau negatif dana untuk memprediksi nilai dari variabel dependen, apabila nilai variabel independen mengalami kenaikan atau penurunan. Subjek penelitian dalam penelitian ini adalah populasi merupakan keseluruhan unit atau individu dalam ruang lingkup yang ringan diteliti, populasi dibatasi sebagai jumlah siswa paling sedikit mempunyai sifat yang sama. 


\section{HASIL TEMUAN}

Sebelum melakukan penelitian, angket kecemasan dan minat belajar matematika siswa dilakukan uji coba instrument. Adapun uji coba yang dilakukan dalam penelitian ini adalah uji validitas dan reabilitas. Untuk lebih jelasnya perhatikan penjelasan dibawah ini.

\section{Uji Coba Instrumen}

Berdasarkan hasil penelitian, diperoleh nilai sig. reabilitas sebesar 0,680. Karena nilai sig. lebih besar dari 0,05 maka data tersebut realib. Sehingga angket kecemasan belajar matematika siswa dapat digunakan dalam penelitian ini.

Berdasarkan hasil penelitian, didapat nilai $r_{x y}$ hitung dan $r_{x y}$ tabel. Jika $r_{x y}$ hitung lebih besar dari $r_{x y}$ tabel maka data tersebut valid. Sebaliknya jika $r_{x y}$ hitung lebih kecil dari $r_{x y}$ tabel maka data tersebut tidak valid. Dari 25 item pernyataan minat matematika siswa hanya 20 item yang valid. Dengan demikian item yang digunakan dalam penelitian ini ada 20 item pernyataan tentang minat belajar matematika siswa.

2. Deskripsi Kecemasan Belajar Siswa Untuk mendeskripsikan kecemasan belajar siswa dengan menggubakan rumus indeks. Adapun hasil deskrpisinya terlihat bahwa rata-rata jawaban siswa pada angket kecemasan belajar sebesar 11,17\% yang mendapat skor 1. Dan rata siswa menjawab pada skor 2 dan 3 sebesar $44,00 \%$ dan $35,33 \%$. Paling sedikit siswa menjawab dengan skor 4 yaitu 5,83\%. Selanjutnya rata-rata nilai indeks pada angket kecemasan belajar siswa sebesar $57,13 \%$. Hal ini menunjukkan masih banyak siswa yang merasa cemas dalam belajar.

3. Deskripsi Minat Belajar Matematika Deskripsi minat belajar matematika siswa bertujuan untuk mengetahui sejauh mana minat siswa dalam belajar matematika. Berdasarkan hasil penelitian terlihat bahwa rata-rata jawaban siswa pada angket minat belajar matematika siswa sebesar $12,33 \%$ yang mendapat skor 1. Dan rata siswa menjawab pada skor 2 dan 3 sebesar 33,50\% dan 32,67\%. Dan pada siswa menjawab dengan skor 4 yaitu $5,83 \%$. Selanjutnya rata-rata nilai indeks pada angket minat belajar matematika siswa sebesar $57,13 \%$. Hal ini menunjukkan masih banyak siswa yang merasa tidak berminat dalam belajar.

\section{Uji Prasyarat}

Sebelum menghitung analisis data untuk uji hipotesis, akan di hitung dengan uji prasyarat. Uji prasyarat dalam penelitian ini adalah uji normalitas, uji homogenitas dan uji linieritas. Kriteria pengujian, jika signifikan yang diperoleh lebih besar dari 0,05, maka sampel berasal dari populasi yang berdistribusi normal dan jika signifikan yang diperoleh lebih kecil dari 0,05 maka sampel bukan berasal dari populasi yang berdistribusi normal. Untuk menguji hipotesis tersebut digunakan uji Kolmogorov-Smirnov.

Berdasarsarkan tabel diatas, dapat terlihat bahwa hasil sig. kecemasan belajar dan minat belajar matematika siswa sebesar 0,200 dan 0,165. Karena kedua nilai sig. tersebut lebih besar dari 0,05 maka data tersebut berdistribusi normal. sehingga uji prasyarat ini terpenuhi. Uji prasyarat selanjutnya adalah uji homogenitas. Kriteria untuk pengujian homogenitas dengan menggunakan uji Levene Statistic sebagai berikut:

Jika nilai signifikan $>0,05$, maka varian kelompok data homogen.

Jika nilai signifikan $<0,05$, maka varian kelompok data tidak homogen.

Berdasarkan tabel di atas, bahwa nilai sig. homogenitas pada data tersebt adalah 0,457. Sehingga nilai sig. 0,457>0,05 maka hasil kemampuan pemahaman 
konsep tersebut berdistribusi sama (varians homogen).

Uji linieritas merupakan uji prasyarat yang digunakan dalam penelitian ini. Kriteria uji linieritas adalah jika nilai Deviation from Linearity sig. > 0,05, maka ada hubungan linier secara signifikan. Dan jika nilai Deviation from Linearity sig. < 0,05, maka tidak ada hubungan linier secara signifikan.

Berdasarkan hasil penelitian, nilai sig. deviation from linearity sebesar 0,922. Sehingga niali sig. deviation from linearity lebih besar dari 0,05. DengaN demikian ada hubungan linier kecamasan belajar terhadap minat belajar matematika siswa. Setelah uji prasyarat terpenuhi selanjutnya untuk uji hipotesis penelitian ini dengan uji korelasi.

Berdasarkan hasil penelitian di peroleh nilai korelasi product moment sebesar 0,417. Hal ini menunjukkan bahwa terdapat pengaruh yang kuat kecemasan belajar siswa terhadap minat belajar matematika siswa. Sehingga diharapkan seorang guru dapat membantu siswa dalam menghadapi kecemasan dalam belajar sehingga dapat meningkatkan minat belajar matematika siswa. Interpretasi Output Analisa Korelasi Person di atas dibagi menjadi 3 bagian,yaitu:

1. Melihat tingkat kekuatan (keeratan) hubungan antara variabel kecemasan belajar dengan minat belajar.

Dari output hasil penelitian, diperoleh angka koefisien korelasi sebesar 0,417 yang berarti bahwa tingkat kekuatan hubungan (korelasi) antara variabel kecemasan belajar dengan minat belajar sebesar 0,417. Dapat dilihat pada output diatas, hasil perhitungan korelasi tersebut dilengkapi tanda bintang yang mengartikan bahwa korelasi tersebut bernilai signifikan pada angka singnifikansi sebesar 0,05.
2. Melihat jenis hubungan variabel kecemasan belajar dengan minat belajar.

Angka koefisien korelasi pada hasil diatas bernilai positif, yaitu 0,417 sehingga hubungan kedua variabel tersebut bersifat searah, dengan demikian dapat diartikan bahwa semakin tinggi kecemasan belajar yang dialami maka semakin tinggi juga minat belajarnya.

3. Melihat signifikansi hubungan kedua variabel.

Berdasarkan output hasil penelitian di atas, diketahui nilai signifikansi atau Sig.( 2tailed) sebesar 0,022 yang nilainya lebih kecil dari 0,05 sehingga terbukti ada hubungan yang signifikan (berarti) antara variabel kecemasan belajar dengan minat belajar.

Mengacu pada uraian hasil output penelitian diatas, maka kesimpulan dalam penelitian ini adalah ada hubungan signifikan dan searah antara variabel kecemasan dengan minat belajar.

\section{PEMBAHASAN}

Berdasarkan hasil penelitian diperoleh nilai korelasi product moment sebesar 0,417. Hal ini menunjukkan bahwa terdapat pengaruh yang kuat kecemasan belajar siswa terhadap minat belajar matematika siswa. Sehingga diharapkan seorang guru dapat membantu siswa dalam menghadapi kecemasan dalam belajar sehingga dapat meningkatkan minat belajar matematika siswa. Interpretasi Output Analisa Korelasi Person di atas dibagi menjadi 3 bagian,yaitu:

1. Melihat tingkat kekuatan (keeratan) hubungan antara variabel kecemasan belajar dengan minat belajar. Dari output hasil penelitian, diperoleh angka koefisien korelasi sebesar 0,417 yang berarti bahwa tingkat kekuatan hubungan (korelasi) antara variabel 
kecemasan belajar dengan minat belajar sebesar 0,417. Dapat dilihat pada output diatas, hasil perhitungan korelasi tersebut dilengkapi tanda bintang yang mengartikan bahwa korelasi tersebut bernilai signifikan pada angka singnifikansi sebesar 0,05.

2. Melihat jenis hubungan variabel kecemasan belajar dengan minat belajar. Angka koefisien korelasi pada hasil penelitian di atas bernilai positif, yaitu 0,417 sehingga hubungan kedua variabel tersebut bersifat searah, dengan demikian dapat diartikan bahwa semakin tinggi kecemasan belajar yang dialami maka semakin tinggi juga minat belajarnya.

3. Melihat signifikansi hubungan kedua variabel. Berdasarkan output hasil penelitian di atas, diketahui nilai signifikansi atau Sig.( 2-tailed) sebesar 0,022 yang nilainya lebih kecil dari 0,05 sehingga terbukti ada hubungan yang signifikan (berarti) antara variabel kecemasan belajar dengan minat belajar. Mengacu pada uraian hasil penelitain hasil output di atas, maka kesimpulan dalam penelitian ini adalah ada hubungan signifikan dan searah antara variabel kecemasan dengan minat belajar.

\section{SIMPULAN}

Berdasarkan uraian dari hasil penelitian, maka dapat di tarik kesimpulan dari penelitian ini adalah:

Terdapat adanya hubungan kecemasan siswa terhadap minat belajar matematika, atau dengan kata lain minat belajar matematika sama sekali ada hubungan oleh rasa cemas siswa dalam minat belajar matematika dalam menghadapi ujian khususnya dalam mata pelajaran matematika.

Tidak terdapat hubungan minat belajar matematika, atau dengan kata lain minat belajar matematika tidak ada hubungan minat belajar matematika yang dimiliki siswa tersebut dalam pembelajaran matematika. Hubungan kecemasan yang terjadi antara minat belajar matematika terhadap kcemasannya negatif.

Secara stimulus, rasa cemas terhadap minat belajar terbukti memiliki andil untuk mempengaruhi hubungan kecemasan siswa terhadap minat belajar matematika.

\section{DAFTAR PUSTAKA}

Aritonang, Keke T. (2008). "Minat dan Motivasi dalam Meningkatkan Hasil Belajar Siswa". Jurnal Pendidikan Penabur, 7(10): 11-21.

Atikah. (2011). Faktor-faktor yang Berpengaruh Terhadap Kecemasan Orang Tua akan Keselamatan Remaja. Fakultas Psikologi: UIN Syarif Hidayatullah Jakarta.

Dinar, Barokah. (2001). Indikator Minat Belajar Siswa. (online ).(http:pedoman skripsi. Blogspot.com /2011/07/indikator, diakseskan tanggal 10 Desember 2016).

Herry. (2015). Pengaruh Minat dan Motivasi dalam meningkatkan Hasil Belajar siswa. (online). (http//rikoyutra. Blogspot. com, diakseskan tanggal 10 Desember 2016).

Manula, Yunitasari. (2013). Masalah Belajar Peserta Didik. (online). (http:yunitasarimanula.wordpress. com/2013/19/cara menentukan siswa yang mengalami masalah minat belajar diakses tamggal 12 Desember 2016.

Siagian, Roida E V. (2011). "Pengaruh Minat dan Kebiasaan Belajar Siswa Terhadap Preatasi Belajar Matematiaka" Jurnal Formati , 2(2): 122-131. 
Pengaruh Kecemasan Terhadap... - Eriyanti, Rachmadhani, \& Machrani

Slameto. (2010). Belajar dan Faktor- faktor

Yang Mempengaruhi, Jakarta Rineka Cipta.

Sudjana, Nana. (2011). Penilaian Hasil Proses Belajar Mengajar. Bamdung:

Remaja Rosda. 